\title{
Apresentação Dossiê Arquivos e História da Educação
}

\author{
ALEXANDRA LIMA DA SILVA \\ MARIA CELI CHAVES VASCONCELOS
}

Este número da Revista Caminhos da Educação traz o Dossiê temático Arquivos e História da Educação, organizado pelas professoras Alexandra Lima da Silva e Maria Celi Chaves Vasconcelos. A ideia deste Dossiê surgiu na disciplina Estudos Avançados em História da Educação II, ministrada no primeiro semestre de 2021, no Programa de PósGraduação em Educação da Universidade do Estado do Rio de Janeiro.

A referida disciplina, obrigatória para o curso de doutorado, procura refletir a respeito do debate proporcionado pela renovação historiográfica, privilegiando o exame de questões relativas à escrita da história da educação brasileira, sujeitos, instituições e saberes envolvidos nesta prática.

A partir da conversa com pesquisadoras do campo, e da leitura do livro (DES)ARQUIVAR: Arquivos Pessoais e ego-documentos do Tempo Presente, de Maria Teresa Santos Cunha (2019), a turma foi instigada a produzir artigos a respeito dos Arquivos e História da Educação.

$\mathrm{Na}$ linha do que propõe Cunha, o “dever de memória” propicia protagonismo aos arquivos pessoais, institucionais, públicos e privados, renovando a pesquisa e deslocando a lógica do documento/monumento, para dar espaço aos guardados, às coleções, aos egodocumentos, aos recortes, aos arquivos escolares, aos impressos, aos acervos digitais, enfim, a um infinito de possibilidades que se abrem ao pesquisador que, por meio de suas indagações, pode transformá-los em fontes.

É com essa finalidade que apresentamos o Dossiê em pauta, cujos artigos que se

a Universidade do Estado do Rio de Janeiro. Doutora em Educação, e-mail: alexandralima1075@gmail.com

b Universidade do Estado do Rio de Janeiro. Doutora em Educação, e-mail: maria2.celi@gmail.com

Rev. Caminhos da Educação: diálogos, culturas e diversidades, Teresina, v. 3, n. 2, p. 2-3, Mai./Ago. 2021 
debruçam sobre diferentes tipologias de arquivos, buscando examiná-los, confrontá-los e analisá-los na perspectiva da história da educação.

O artigo Arquivos Digitais: possibilidades de pesquisa no campo da História da Educação, de Daise Silva dos Santos procura discutir a importância dos arquivos digitais num cenário de pandemia de COVID-19.

Em Escritas Migrantes e Escritas Refugiadas como formação de identidades de mulheres na diáspora, Rosane Pereira Marques explora as possibilidades das escritas de mulheres na diáspora em situações de vulnerabilidade e também as questões que perpassam gênero e xenofobia, além da importância da educação para mulheres e meninas, que ocorre paralelamente à feminização da migração e do refúgio.

O artigo Onde está Maria Beatriz Nascimento na história da educação? Algumas reflexões sobre apagamentos e direito à memória, de Rosineide Freitas, objetiva contribuir com as reflexões sobre a importância de intelectuais negras para as pesquisas em Históriada Educação, a partir da trajetória de Maria Beatriz Nascimento, historiadora e intelectualnegra do tempo presente.

Por fim, o artigo De vida infantil à vida juvenil: uma jornada pelos arquivos, de Mariana Elena Pinheiro dos Santos de Souza, busca traçar um panorama relativo à relação arquivos e periódicos voltados ao público infanto-juvenil. 